\title{
THE UNITED STATES VIRGIN ISLANDS AND DECOLONIZATION OF THE EASTERN CARIBBEAN
}

\author{
William W. Boyer*
}

The United States Virgin Islands are a group of small islands, constituting the easternmost point of U.S. territory, located midway in the great curving archipelago of Caribbean Islands-stretching from Cuba to Trinidad-with the Greater Antilles to the west and the Lesser Antilles to the east and south. Indeed, the U.S. Virgin Islands-consisting of the three main islands of St. Thomas, St. John, and St. Croix-form the westernmost and beginning part of the slope of the Leeward Islands of the Lesser Antilles. Together with the Windward Islands of the Lesser Antilles comprising the southern part of the chain, these islands collectively form the Eastern Caribbean region.

\section{Affinity With the East}

Although St. Thomas and St. Croix are only 40 to 50 miles to the east of Puerto Rico, and nearly half the population of St. Croix is of Puerto Rican descent, most of the approximately 100,000 U.S. Virgin Islanders identify more closely with the English-speaking Eastern Caribbean of which they are a part than with the Hispanic Caribbean to the west.

Reasons for their affinity with the east are several. Foremost, of course, is that by 1965 over half the work force of the U.S. Virgin Islands comprised immigrant workers from the British islands of the Eastern Caribbean. Aside from the British Virgin Islands, foreign workers in the U.S. Virgin Islands were drawn principally from the British-connected islands of the Eastern Caribbean-Anguilla, Antigua, Barbados, Dominica, Grenada, Montserrat, Nevis, St. Kitts, St. Lucia, St. Vincent, and Trinidad. The contributions of the Eastern Caribbean to the social, economic, and political culture of the U.S. Virgin Islands cannot be overstated. Carnival, the steel bands, cricket, soccer, certain foods and beverages originated in the Eastern Caribbean islands of the migrants. Their greatest contribution, of course, has been to the economic development of the Virgin Islands.

Secondly, St. Thomas and St. John are only a few miles from the British Virgin Islands and, historically, there has been a free movement of inhabitants between the British and U.S. Virgin Islands. By the time of the transfer of the Islands to the U.S. in 1917, approximately 21 percent of the population of the U.S. Virgin Islands had been born in the British Virgin Islands, and over 60 percent of the present population of St. Thomas alone is descended from the nearby British Virgin Islands. Immigrants from the British islands of the Eastern Caribbean, moreover, have more easily assimilated and intermarried with the so-called native Virgin Islanders, because of their similarity "in habits, physique, language, traditions, race, and color," than have those coming from the Hispanic Caribbean. ${ }^{1}$

Finally, the U.S. Virgin Islands share with most other Eastern Caribbean islands the same geologic and volcanic origins, a comparatively arid climate marked by frequent droughts, and a common history of plantation agriculture built on slavery and the monoculture of sugar.

\footnotetext{
*Charles Polk Messick Professor of Public Administration, Department of Political Science, University of Delaware. This article is adapted and revised from the Distinguished Scholar Lecture, "Self-Determination for the U.S. Virgin Islands-Myth or Reality?" presented at the College of the Virgin Islands, St. Croix, December 2, 1982, and St. Thomas, December 3, 1982, by the author while serving as Visiting Professor of Social Sciences.
} 
Considering its affinity with the English-speaking Caribbean, it is little wonder then that the U.S. Virgin Islands have been vitally affected by the wave of independence that has swept the former British colonies of the Caribbean. Over the past 22 years, 12 new nations have been born in the Caribbean Basin beginning with Jamaica and Trinidad-Tobago in 1962; followed by Guyana and Barbados in 1966; Grenada in 1974; Surinam in 1975; Dominica in 1978; Belize, St. Vincent and the Grenadines, St. Lucia, and Antigua-Barbuda from 1978 through 1982; and finally St. Kitts-Nevis in 1983. All but Belize, Jamaica, Guyana, and Surinam are in the Eastern Caribbean, and all but Surinam are former British colonies.

In short, the U.S. Virgin Islands are experiencing an identity crisis. Should they move in the direction of their neighbors-toward independence? Or should they remain a part of the United States? And, if the latter, should they remain indefinitely in their present anomalous position of belonging to America without their people knowing just how American they are?

An issue of growing public concern in the U.S. Virgin Islands, therefore, is the issue of self-determination. In this era of quickening decolonization in the Caribbean Basin and elsewhere, and of the posturing of the United States as the world's champion of human rights, it is pertinent to ask what, if anything, the United States has done, is doing, and will do regarding self-determination of the people of the U.S. Virgin Islands which occupy the lowest rung of the U.S. colonial ladder.

Webster's Dictionary defines "self-determination" as "the right of a people to decide upon its political status or form of government without outside influence." To address the question whether self-determination is a myth or reality in the U.S. Virgin Islands, it is instructive to reach back into the history of the U.S. Virgin Islands, for in order to understand the present, let alone to project to the future, it is first necessary to understand the past. The uses of history, therefore, are practical.

Have the people of the U.S. Virgin Islands in the past enjoyed this right? Do they enjoy this right now? Will they enjoy self-determination in the future? These are the questions addressed in this article. First, have Virgin Islanders enjoyed this right in the past?

\section{The Past}

Denmark sold the Virgin Islands to the United States in 1917 for $\$ 25$ million in gold. ${ }^{2}$ That which is not generally known, however, is that the United States threatened to take over the Islands by force unless Denmark agreed to sell them. ${ }^{3}$ Moreover, the United States took possession of the Islands without gaining the consent of their inhabitants (no plebiscite was held as Denmark requested), and many believed they would be accorded American citizenship when in fact they were denied that status. ${ }^{4}$

After the United States had acquired the extracontinental insular possessions of Puerto Rico, the Philippines, and Guam by its defeat of Spain in the Spanish-American War, the Supreme Court declared for the first time that the U.S. Constitution of its own force did not follow the American flag to these new possessions and that their inhabitants had only those rights extended to them by Congress-not by the highest law of the land, the Constitution. ${ }^{5}$ The author of this new doctrine was Justice Edward White who had served in the Confederate Army during the Civil War. It was apparent that Justice White was concerned with "racial" questions. He felt that Constitutional rights should not extend automatically to the non-white populations of the new possessions. ${ }^{6}$ Thus, the Supreme Court reversed the principle of equality - set forth in the Declaration of Independence of 1776, and in all subsequent arrangements for territorial acquisitions until the Spanish-American War-that Congress, when legislating on the civil rights of the inhabitants of the territories, was governed by all those expressed and implied Constitutional limitations which rest upon it when dealing with the same subjects within the States. It was a short step, therefore, to extend the same logic to the U.S. Virgin Islands and to withhold U.S. citizenship to their mostly black inhabitants. ${ }^{7}$

Navy Rule, 1917-1931

Without having to heed the U.S. Constitution, therefore, the all-white U.S. Navy ruled the overwhelmingly black population of the Virgin Islands from 1917 to 1931. Many Virgin Islanders mistakenly thought that U.S. citizenship had been automatically bestowed on those among them who had not chosen Danish citizenship under the terms of the treaty of purchase. They mistakenly thought they would be given the right to vote and a large measure of self-determination. And they mistakenly thought that American sovereignty would result in greater employment, higher wages, and an end of their poverty. 
On all counts they were wrong. None of these aspirations was to be fulfilled for many years to come.

Navy administrators were unalterably opposed to those native leaders who agitated for a greater measure of self-determination. ${ }^{8}$ For example, Rear Admiral James Oliver, the first American governor, reported in 1919 to the Director of Naval Intelligence in Washington that Rothschild Francis is "a sort of half-witted negro ... apparently without an occupation ... constantly causing agitation among the ignorant class," and that D. Hamilton Jackson "has since forming a labor union been instrumental in causing a great deal of unrest amongst the natives" and whose "followers . . . stand by him in his crookedness." Governor Oliver concluded this scurrilous report by stating: "I, therefore, earnestly recommend that ... the Attorney General ... be requested to send a capable, trusted, and energetic

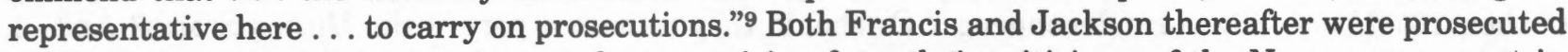
and imprisoned on contempt of court charges arising from their criticisms of the Navy government in their newspapers.

By 1927, before ten years of Navy rule had expired, the Islands had already experienced six governors, among whom were those who unmistakenly were white supremacists. For example, Navy Governor Sumner Kittelle wrote President Warren Harding in 1922: "I cannot too strongly urge that there be no change made in the organic law until a full generation has elapsed . . . and above all the white element must remain in the land and in supreme control. ${ }^{10}$ Government Secretary C. C. Timmons opposed widening of the suffrage for fear it would presage all-black juries, and, therefore, "a person of the Caucasian race might not be entirely safe before such a jury."11

At the very least, most Virgin Islanders were disappointed with American suzerainty over the Islands. They were unprepared for the worsening of the already slackening economy and for Washington's indifference. Their initial enthusiasm for transfer to American rule was dampened further by Washington's alleged reneging on the grant of citizenship together with the Navy's infusion of racism, repression, autocracy, and Americanization-all interrelated features of insular life under Navy rule. The Navy's achievements, particularly in health and education, paled in comparison to the growing discontent of Virgin Islanders. Most grievous, perhaps, was the postponement of any semblance of self-determination and political democracy.

It was not surprising, therefore, that many Virgin Islanders—including Rothschild Francis-migrated to the continental United States, especially to New York City, subsequent to the bestowal on Virgin Islanders of U.S. citizenship in 1927, ten years after the transfer. Indeed, New York City boasted almost as many Virgin Islands residents as lived in the Virgin Islands in 1930. The total population of the Virgin Islands in 1930 was little more than half the population of a century before. Commensurate with the steady economic decline, the total decreased from 26,051 in 1917-the year of the transfer to American rule-to 22,012 in 1930 .

During the fourteen years of Navy rule, certainly the people of the Virgin Islands cannot be said to have experienced any measure of self-determination. To rehabilitate the economy of the Islands, President Herbert Hoover transferred jurisdiction over them from the Navy to the Interior Department in 1931 and appointed Dr. Paul M. Pearson of Swarthmore, Pennsylvania, to be the first civilian governor of the Islands.

A New Deal

With the end of Navy rule and the onset of civil government, despair of the destitute turned to hope. Their aspirations, however, were soon dashed by President Hoover, himself. Eight days after Governor Pearson's inauguration, Hoover became the first U.S. President to visit the Islands, ostensibly to bolster rehabilitation. After five hours on St. Thomas, he made this ill-fated statement:

The Virgin Islands may have some military value some time. Opinion upon this question is much divided. In any event, when we paid $\$ 25,000,000$ for them, we acquired an effective poorhouse ... Viewed from every point except remote naval contingencies, it was unfortunate that we ever acquired these islands . . .12

Richard Oulahan of The New York Times reported that President Hoover had little faith that the people of the Virgin Islands "will react favorably to the principle of self-help," and that his derision of Virgin Islanders evidently was motivated by ethnic or racial considerations because of this concern over "the immigration question." Unrestricted emigration of Virgin Islanders and Puerto Ricans to New York, according to Oulahan, gave "the administration food for thought, in the light of the quota limitations placed on the immigrants from certain European countries who make especially desirable citizens."13 
Whatever motives prompted Hoover to make his "poorhouse" comments, no Presidential statement could have been more calculated to offend the pride and dignity of Virgin Islanders and to degrade the poor among them.

Despite the cloud cast by Hoover's skeptical pronouncement, Governor Pearson vigorously pressed economic reform of the Islands, the first governor in a century-since von Scholten who freed the slavesto exhibit such compassion for the Islanders. To increase responsibility by the Islanders for their own government, Pearson filled 75 percent of administrative and executive posts with Virgin Islanders. Notable improvements were accomplished in economic conditions, education, health, sanitation, and employment. Nevertheless, Pearson's tenure as governor was marked by mass demonstrations against him and by social unrest that finally provoked President Franklin Roosevelt to remove him. ${ }^{14}$

Given these admirable achievements of the Pearson administration, the question arises why most Virgin Islanders were not content during Pearson's tenure as governor. They betrayed no gratitude for American attempts to advance economic emancipation of the Islands. Indeed, with the Islands being a focus of much unprecedented ferment and activity, Virgin Islanders of every station responded with malevolence and vituperation toward their would-be benefactors. Reasons for this apparent anomaly are speculative, but certain factors are probably suggestive of explanation.

Perhaps a distinctive insular psychology, borne of isolation and alienation from the mainland, enlarged or distorted dissent into misanthropic mass demonstrations. After all, Virgin Islanders had no experience with American politics and its elements of compromise, free expression, give-and-take, and the corollary of an extraordinary toleration of political-if not ideological-differences. The mass of Virgin Islanders still could not vote. They could not feel any sense of participation in the making of decisions about their destiny. They were still being ruled by Washington, when in fact they desperately wanted to rule themselves. They had always been put down by others. How could they now be expected to trust the wisdom of the white men who had replaced the naval officers? At a mass rally of Virgin Islanders in Harlem, in 1934, Casper Holstein stated:

We cannot enjoy half slavery and half freedom. We want it all or nothing. We don't want to be revolutionists; we don't want to be communists; we don't wish to be branded against organized government. We want to be the same as every member of the American nation, and we are entitled to that privilege. I am told you cannot oppose government, but, by God, government can hear us cry, and must hear us protest until we get the form of government we wish.15

Perhaps, also, the people of the Virgin Islands had been repressed for so long, that now they were letting off steam, and conditions had changed under civil rule permitting them to vent their long-time, pentup discontent. Every governor succeeding Pearson was to feel the steam of popular discontent, probably attributable to some if not most of the factors at work in the $1930 \mathrm{~s}$.

One must also be mindful that despite their location, Virgin Islanders have always been strongly influenced by developments and events elsewhere featuring popular assertiveness and political participation-in the United States, the Caribbean, and the world. Bonus armies, civil rights movements, anti-colonialism, the new nationalism, and the so-called new international economic order have all influenced Virgin Islanders. However compassionate and noble were the motives behind it, Pearson's New Deal may have heightened the sense of the people's dependency and lack of self-determination, counter to their quest for dignity and integrity. It certainly made them early participants in the coming revolution of rising expectations that was to sweep the Eastern Caribbean and the rest of the third world. In this sense, only a political system of self-determination and an economic system of selfsufficiency ultimately could ever fulfill their rising expectations.

In many respects, the Virgin Islands in the 1930s consisted of a heterogeneous, transitional society beset with the intrusion of radical, exogenous forces by continental architects bent on economic reconstruction for altruistic reasons. Had New Deal actors pressed rehabilitative enterprise in a manner completely consonant with, and responsive to, the personality and culture of the Virgin Islands-that in itself would not have assured success of the New Deal in the Islands. Their lack of cultural empathy, however, probably did assure, if not hasten, the demise of the self-help rehabilitative efforts, and helped forge, in their stead, a permanent dependency relationship with the metropolitan government in Washington. This trend was directly opposite to self-determination. 
The 1936 Organic Act is frequently cited as the Island's first constitution by which Congress conferred a great measure of self-determination. It is true that elected municipal councils replaced the old colonial councils and that the grant of universal suffrage to those able to read and write English opened the political process to all classes and would break the long-time monopoly of political power of the planters and merchants. All federal taxes collected in the Islands, moreover, were to be retained in the territory. The U.S. President still appointed the governor, government secretary, and district judge, however, and the President could disapprove an override of a governor's veto. The Secretary of Interior, furthermore, was given the power to appoint other federally-funded executive and administrative officers. ${ }^{16}$

From Arrogance to Promise

The 1936 Act fostered for the first time the formation of local political parties and the passage of local social legislation, and ten years later President Truman appointed the Islands' first black governorWilliam Hastie. But these gains were not tantamount to self-determination. The territory was still administered from Washington, and Virgin Islanders still had no power to determine their own political status or form of government. They were utterly dependent, governmentally and economically, on Washington, and what Washington gave Washington could take away.

The Revised Organic Act of 1954 expanded the suffrage even further by eliminating the English literacy requirement, thus enabling the growing number of Spanish-speaking Islanders to vote. And the act provided for annually paying into the treasury of the government of the Virgin Islands an amount equal to federal revenues collected on articles produced in the Virgin Islands, including rum. Not only did the 1954 Act continue, however, the Presidential appointment of the governor and governor secretary, and made no provision for an elected resident commissioner in Congress-evoking bitter disappointment of Virgin Islanders-but it also required Presidential approval of certain expenditures, required the governor to reorganize the Virgin Islands government into no more than nine executive departments, and required prior approval by the Secretary of Interior for the creation of any other administrative agency. ${ }^{17}$ These provisions, commented James Bough, instead of increasing self-government, "took away from the Virgin Islands and redeposited into the hand of the bureaucracy in Washington a large measure of control over the territorial governmental machinery." 18

Claiming that "we enjoy considerably less self-government than we did in 1936," Virgin Islanders renewed their long-time demands for the right to elect their own governor, to be represented in Congress by a resident commissioner, and to legislate on internal matters. Their campaign was fueled in 1958 by the formation on January 3rd of that year of the British West Indies Federation, comprised of ten Caribbean island units-Jamaica, Trinidad and Tobago, Barbados, Grenada, St. Vincent, St. Lucia, Dominica, Antigua, St. Christopher (St. Kitts)-Nevis-Anguilla, and Montserrat. The Federation was established to prepare their more than three million inhabitants to move as rapidly as possible toward the attainment of independence within the British Commonwealth. American Virgin Islanders compared their own continuing colonial status with the promise of comprehensive self-government to their British neighbors. ${ }^{19}$

Contrasting sharply with these developments was the aftermath of a fire that January in St. Thomas which destroyed the newly constructed redwood home of a friend of the visiting Secretary of Interior, Fred Seaton, who apparently insisted that heads must roll. The morning after the fire, the chief of police, who was on leave at the time of the fire, and the commissioner of public safety were both summarily dismissed, whereas the fire chief who failed to save the house was spared. The local public was "incensed . . over this apparent injustice."20 This event triggered a demonstration on January 29, 1958 of three thousand Virgin Islanders-led by Valdemar Hill, President of the Virgin Islands Unity Party, and Senator Earle B. Ottley-who marched on Government House petitioning the removal of California Governor Walter Gordon "because of his incompetence, abuse of powers, and bad administration," and declaring their readiness for "the responsibilities of self-government."

Washington officials voiced disapproval of the demonstration and California Congressman Clair Engle, Chairman of the powerful House Interior and the Insular Affairs Committee, irately responded: "In the event any sizeable group of Virgin Islanders demands self-government and independence from the United States, I stand ready to introduce legislation to achieve that status."21

In retrospect, this marked the zenith of arrogance on the part of Washington luminaries, for President Eisenhower soon replaced Governor Gordon with the Islands' first native-born governor-John Merwin 
of St. Croix - who promptly appointed for the first time an all-native cabinet. Although Governor Merwin supported an elective governor and resident commissioner in Congress, he was against having an elected resident commissioner while the governor was still appointive, because such an arrangement "could put me on the spot," he said, especially in his relations with the insular legislature. Both President Eisenhower in his 1960 and 1961 budget messages and Interior Secretary Fred Seaton, as well as Puerto Rico's Resident Commissioner Antonio Fernos-Isern, announced their support for the Virgin Islands to have a non-voting delegate or resident commissioner in Congress. The 1960 national platform of the Republican Party added its endorsement to the earlier endorsement by the Democratic Party. Before the United Nations, U. N. Delegate Senator Wayne Morse proclaimed the death of colonialism under the American flag by noting that Guam had acquired its first indigenous governor, while in the Virgin Islands there had been a native-born governor for "some time."22

Despite growing external support for a non-voting delegate, including unanimous approval by a Congressional subcommittee, continuing demands by Virgin Islanders for more self-government were not to succeed for several years.

Even more significant than the replacement of Washington's arrogant posture with growing national support for more self-government was the surprising pledge to the people of the Virgin Islands by Assistant Secretary of the Interior John A. Carver on April 5, 1961 at Ralph Paiewonsky's inauguration as governor. Carver announced a new and major policy direction for the federal government in its relationship with the government of the Virgin Islands. In recognizing the federal government's continuing responsibilities to the people of the Virgin Islands, Carver voiced the most far-reaching promise of self-determination ever offered them. He emphasized that the federal government would look to the people to identify their problems and to express their hopes and aspirations including "a free choice as to their ultimate form of relationship with the United States." Given the fact that under the so-called territorial clause of the U.S. Constitution-Article IV, section 3, clause 2-only Congress had plenary power to determine territorial relationships with the United States, one wonders about the source of Carver's authority for his remarkable offer. In any event, he concluded his address with these words: "In conclusion, let it be said it is not the intention of the Department of the Interior to impose 'administration."'23

At the outset of his administration, therefore, Governor Paiewonsky was given an unprecedented degree of freedom to run the Virgin Islands without much fear of federal interference; and with the help principally of Senator Earle B. Ottley-he made the most of his opportunity. Most significant, however, was Carver's promise to the people of the Virgin Islands of ultimate self-determination. Was this mere inauguration-day rhetoric? Or was he announcing an irreversible pledge of the United States government?

Thereafter, Congress chose to address the matter of more self-government for the Virgin Islands on a piecemeal rather than on a package basis. After several false starts, Congress passed the Elective Governor Act of 1968, and Virgin Islanders elected their own governor and lieutenant governor for the first time in 1970. The Act also abolished the Presidential veto of territorial legislation and authorized the legislature to override the governor's veto by a two-thirds majority vote. ${ }^{24}$ Other legislation authorized Virgin Islanders to elect beginning in 1972 a non-voting delegate to Congress. ${ }^{25}$

All of these measures had been specifically proposed by the thirty-three elected delegates to the Constitutional Convention of 1965 established by the Virgin Islands Legislature to draft a Second Revised Organic Act. But the convention's proposals that Virgin Islanders have a right to vote for the President and Vice President of the United States, and for the governor to appoint the comptroller, have not been authorized. It is interesting to note that the 1965 convention went on record to reject independence, annexation to any state of the Union, or any change in the Islands; status as an unincorporated territory. ${ }^{26}$

A second constitutional convention was authorized by the Virgin Islands Legislature in 1971. Its resulting proposed constitution and Federal Relations Act were approved in 1972 by more voters than those who rejected the two documents. However, because of a large number of blank ballots, the votes in favor totaled less than half of the ballots cast. Accordingly, the two documents were not submitted to Congress. ${ }^{27}$ Instead, Congressional Delegate Ron de Lugo introduced legislation in Congress in 1974 to authorize the people of the Virgin Islands to organize a government pursuant to a constitution of their own adoption. 
Congress passed the enabling legislation in 1976, providing for submission of the proposed constitution by the governor to the President for his review, approval by the Congress, and finally approval by a majority of voters in a local referendum. Congress empowered the constitutional convention to deal with such areas of self-government as the taxing power and the jurisdiction of the local courts, but-most significantly-Congress expressly forbade consideration of the territory's political status or alterations in existing Federal relations. ${ }^{28}$

After failing on two previous attempts through local initiative, the Virgin Islands Legislature-this time pursuant to Congressional action-provided for a third constitutional convention of sixty elected delegates. When the proposed constititution finally was submitted to the voters in March, 1979, less than 38 percent turned out, and of these, 56 percent voted to reject it. In 1980, a fourth constitutional convention convened to make another attempt, but voters once again rejected its proposed constitution in $1981 .^{29}$

So much, then, for consideration of the past in terms of the question whether the people of the Virgin Islands have enjoyed in the past the right of self-determination. Given the definition of "self-determination" as the right of a people to decide upon its political status or form of government without outside influence, the only possible answer to this question is a resounding "NO!"- that Virgin Islanders have not enjoyed the right of self-determination. In effect, Congress reneged on Carver's 1961 promise of selfdetermination by forbidding any constitutional convention to deal with the issue of status or federal relations.

What about the present? Do the people of the Virgin Islands enjoy the right of self-determination now? Let us consider this issue in the context of the present.

\section{The United Nations}

The Present

Under Article 73 of the United Nations Charter, member nations of the United Nations are committed to develop self-government of dependent territories, to take due account of the political aspirations of their peoples, and to assist them in the development of their free political institutions. The United States is a founding member state of the United Nations, a permanent member state of its Security Council, and, of course, a signatory of the U. N. Charter, which, accordingly, has the status of a U.S. treaty under Article VI, clause 2, of the U.S. Constitution-the so-called "supremacy clause"-and, therefore, the U. N. Charter is a part of "the supreme law of the land."

Regarding the U.S. Virgin Islands as a non-self-governing dependent territory, the United States Government since 1946 has transmitted annually to the Secretary-General of the United Nations, pursuant to Article 73 of the Charter, a report on conditions in the Virgin Islands. Nevertheless, despite annual entreaties by the United Nations decolonization committee for it to send a fact-finding mission to the U.S. Virgin Islands, the United States government steadfastly refused to permit such a visit. The Declaration of Independence of 1776 had proclaimed the birth of the United States as being consistent with (to paraphase the Declaration) a decent respect for the opinions of mankind. Had the U.S. now forsworn a decent respect for the world body and the world opinion it represented? Finally, the U.S. relented in 1977 to a visit to the Virgin Islands of a U. N. mission.

After its visit, the United Nations mission noted in its 87-page report that the U.S. Virgin Islands was still a non-self-governing territory and its inhabitants did not enjoy the right of self-determination. Specifically, the report emphasized that the 1976 Congressional enabling legislation for a locally adopted constitution "does not enable the people of the territory to effect any changes in their constitutional relationship with the administering Power." The U. N. Mission therefore urged the United States government, in consultation with the government of the Virgin Islands, "to hold open and meaningful discussions of all available political options open to the Territory" and then "to ascertain the political aspirations of the people through a referendum or plebiscite under observation of the United States." 30

An argument can be made that the Soviet Union is today the world's greatest colonial power. If one defines "colonialism" as the political and economic exploitation of a subjugated people for the benefit of another country, then one can apply colonial status to Poland, Czechoslovakia, Afghanistan and other countries within the Soviet orbit.

If we exclude the Soviet orbit from analysis, then statistics can be quite illuminating, and one can place the U.S. Virgin Islands in a world context. In the entire non-communist world today, there exist 
41 populated dependent territories, only 12 of which are more populous than the U.S. Virgin Islands. Of these 41 dependent territories, 13 are British, 9 are French, and 7 are under U.S. jurisdiction. Such statistics may make the United States vulnerable to an unflattering characterization that it is the noncommunist world's third ranking colonial power.

Because more than 80 million people were considered by the United Nations General Assembly in 1960 to have been still remaining in colonial status, it proclaimed in that year the Declaration on the Granting of Independence to Colonial Countries and Peoples. Between 1960 and 1976, approximately 70 million of that 80 million emerged from dependent status, and 47 more nations gained membership in the United Nations.

According to the United Nations decolonization committee, there remain only 22 territories in the world today which have not yet attained either self-determination or independence and to which the 1960 U. N. Declaration still applies. The U.S. Virgin Islands is listed as one of these twenty-two, and this list is dwindling year by year. Accordingly, the United Nations considers the United States Virgin Islands to be a colony. The United Nations recognizes only two options open for dependent territories to be taken off this list-independence or integration.

Other Caribbean territories to which the Declaration still applies are: the British Virgin Islands, Cayman Islands, Montserrat, and Anguilla. On the other hand, the Declaration is not considered by the United Nations to apply to Puerto Rico, Guadeloupe, Martinque, the Netherlands Antilles, and French Guiana-territories though still not independent are considered nevertheless by the United Nations to have achieved a status of integration or self-government in relation to their respective parent countries. Discussions Begin

Discussions of political options for the U.S. Virgin Islands, as urged by the United Nations missions, were begun in late 1979 by President Carter's White House Interagency Territorial Policy Review Task Force. In response to the Task Force report relating to the status of U.S. territories, Governor Juan Luis asserted in September 1979 that the Government of the Virgin Islands seeks "freer association, similar to the status of Puerto Rico," endorses "the initiation of political status discussions with Congress," and "supports voting representation in Congress and participation in national elections." ${ }^{1}$ It is interesting to note that Governor Romero of the so-called Commonwealth of Puerto Rico in May 1980 characterized "commonwealth" as just another word for "territory," citing a recent U.S. Supreme Court decision that Puerto Rico is still under the Territorial Clause of the U.S. Constitution. ${ }^{32}$ Moreover, were the Virgin Islands to have voting representation in Congress and to participate in national elections, it would have a status dissimilar from that of Puerto Rico which has non-voting representation in Congress and no participation in national elections.

In February 1980, President Jimmy Carter announced in a message to Congress "our nation's fundamental commitment to encourage the self-determined political, economic and social development of our territories." With regard specifically to political development, President Carter elaborated in these significant but curious words:

In keeping with our fundamental policy of self-determination, all options for political development should be open to the people of the insular territories so long as their choices are implemented when economically feasible and in a manner that does not compromise the national security of the United States.

Who was to decide when the terms of these two stated caveats-economic feasibility and national security-were to be met was not clear from the rest of President Carter's statement. However, his statement clearly fixed responsibility for considering any changes in political status on the Secretary of Interior and the Congress. He explained:

If the people of any of the territories wish to modify their current political status, they should express their aspirations to the Secretary of the Interior through their elected leaders, as is the case now. The Secretary, along with representatives of the appropriate Federal agencies, will, in turn, consult with territorial leaders on the issues raised. Following such discussions, a full report will be submitted to the Congress, along with the Secretary's proposals and recommendations. ${ }^{33}$

However conditional or qualified was President Carter's message to Congress with respect to selfdetermination for U.S. territories, his follow-up statement in June 1980 to the Democratic Party Platform Committee must remain the fullest and most unqualified commitment to self-determination ever uttered 
by any American official. In a strongly worded statement, President Carter flatly told the Democratic Party that it:

must be firmly committed to self-determination for Puerto Rico, the Virgin Islands, Guam, American Samoa and the Northern Mariana Islands and vigorously support the realization of whatever political status aspirations are democratically chosen by their people. ${ }^{34}$

To identify political options for the territory and to negotiate status issues with the government in Washington, the Virgin Islands Legislature established in 1980 the Virgin Islands Status Commission which chose Earle B. Ottley as its executive director. At the time, the territory was making its fourth attempt to draft a constitution, but one which Congress expressly prohibited from dealing with the issue of status or federal relations. The Commission was born from the frustration felt about this prohibition. ${ }^{35}$ It was also born from hope that federal policy would be changed. Small polities throughout the Caribbean-especially in the Eastern Caribbean of which the Virgin Islands were a part-were shifting oneby-one to independence. An unprecedented review of federal territorial policy had been initiated by President Carter whose statements now put him clearly on record in favor of self-determination for the territories.

These federal and territorial activities, therefore, made the prospect of self-determination for Virgin Islanders both more real and imminent. President Carter's failure to win re-election in November, 1980 , however, followed by the indifference of the Reagan Administration, effectively ended the flurry of excitement about self-determination. President Reagan's so-called Caribbean Basin Initiative fails to include any prospect of self-determination for the U.S. Virgin Islands.

Meanwhile, the U.S. government has been in the process of according its Pacific trust territory, Micronesia, greater autonomy and self-determination than yet envisaged for the Virgin Islands or Guam. One Interior official explained this seemingly ignominious situation as arising from the fact that the United States has been bargaining with an area over which it can claim no sovereignty, and therefore Micronesia has "more bargaining chips on the table" than has either the Virgin Islands or Guam. ${ }^{36}$

The only conclusion that can be reached, therefore, is that at present the people of the Virgin Islands do not enjoy the right to self-determination. Most Virgin Islanders realize that their long struggle to gain control over their own destiny will continue for years ahead.

It remains, then, to consider the future. Is it likely that Virgin Islanders will ever enjoy the right of self-determination?

\section{The Future}

To consider the future is to engage, of course, in speculation. But the future is an extension of the past and history can be instructive in pointing the way ahead.

Historical Perspectives

In terms of one historical perspective, the history of the Virgin Islands is a history of the struggle of its people for integrity, for dignity, and for the right to determine their own destiny-a struggle first as slaves, then as serfs, and lastly as citizens. It has been a struggle for freedom to enjoy self-determination, and this struggle for freedom-though it has achieved much-still persists and will continue. This struggle for freedom has been the one consistent theme through the past 312 years of the Virgin Islands. So, the force of history would seem to ordain that the Virgin Islands will not remain an unincorporated territory of the United States-that Virgin Islanders will achieve self-determination.

A second historical perspective concerns the history of the United States. As a new nation, the United States was born when thirteen united colonies decided, in the words of the Declaration of Independence, "to assume among the powers of the earth, the separate and equal station to which the Laws of Nature and Nature's God entitle them." It is the moral imperative of its own history as a nation that impels the United States to continue the process of divesting itself of its colonies-a process begun in 1946 with the granting of Independence to the Philippines, followed by statehood to Hawaii and Alaska, and, most recently, by relinquishing suzerainty over the Panama Canal.

A third historical perspective focuses on the world at large and on the Caribbean in particular.

For "God, Glory, and Gold," the advent of empire began with the voyages of Columbus in the last decade of the fifteenth century. Although Vikings and Africans may have had contact with the Western Hemisphere prior to 1492, it was Columbus' achievements that began the almost five centuries of Western imperialism. 
His discovery of what he mistakenly thought was Asia marked the end of the Middle Ages and the rise of the nation state with its concomitants of nationalism and colonialism-a colonialism that was to expand over most of the earth and to enslave many of its inhabitants. The Crusades, Marco Polo, and the Portuguese opening of Africa had set the stage for the adventures of Columbus and his contemporary, Vasco da Gama, that was to kindle such momentous world change.

The end of empire was not to come all at once but was to be protracted over the centuries. Indeed, remnants still persist. The American Revolution of 1776, not the Russian Revolution of 1917, was to provide the dynamism for a waking world. Not until the second half of the twentieth century, however, were empires to be rapidly liquidated.

Historians, generations hence-motivated perhaps by a new ethic-may assess this era of empire as the most barbaric and inhuman in the grand sweep of recorded history. The islands of the Caribbean stood at center stage during the overture of empire and played important parts in the ensuing scenes over the next five centuries - colonialism, slavery, emancipation, war, decolonization, and the so-called East-West and North-South Struggles.

Paradoxically, the Caribbean where Western colonialism began is the last region of the world to experience decolonization. Over the past twenty-two years, of the twelve new nations born in the Caribbean Basin, eight are located in the Eastern Caribbean and two others-Guyana and Surinam-are almost astride the Eastern Caribbean. Both the U.S. Virgin Islands and government in Washington are strongly influenced by this tide of Caribbean independence which surely is propelling the U.S. Virgin Islands ever closer toward self-determination.

Self-determination for the U.S. Virgin Islands would mean that their people would have the opportunity-through a plebiscite or referendum-to choose their own political status from among possible options. Presumably these options would be independence, integration, or an intermediate status.

Independence and Dependence

Independence would mean that sovereignty would be transferred from the United States to the Virgin Islands which would have complete control over all internal matters, the right to conduct relations with other countries, and equal membership in the United Nations.

Many Virgin Islanders believe that economic self-sufficiency is a necessary precondition for independence, and that territorial financial dependence on Washington is too great for independence to constitute a viable status option. The economic dependence of the Virgin Islands on the U.S. government is very substantial, if not overwhelming.

One measure of this dependence is the retention of federal tax revenues in the insular treasury. Under the Revised Organic Act of 1954, not only are all federal income taxes paid in the Islands retained in the insular treasury, but an amount equal to all U.S. taxes on articles produced in the Islands (such as rum) and transported to the U.S. are also paid into the local treasury. This amounts to 100 percent revenue sharing! Meanwhile, the Virgin Islands receives federal grants-in-aid (for purposes such as public housing, child nutrition, and Medicaid, to mention three of the largest) amounting, for example, to $\$ 652$ per capita in Fiscal Year 1977 or 51 percent above the per capita grants to all states and local governments. In addition, not only has Congress authorized substantial federal assistance for capital project expenditures from time to time, but Congress has on several occasions also appropriated extra funds to cover the territory's deficits occasioned by "shortfalls" in income tax collections resulting from federal tax reductions. ${ }^{37}$

Another measure of this dependence is the example of the reliance in the Islands on federal food stamps. Of a population placed officially at about 70,000 persons in the Islands in April 1975, a total of 6,000 families representing 24,957 individuals purchased food stamps, or over 35 percent of the total population-a percentage "probably unduplicated" under the American flag. Virgin Islanders paid \$4.5 million in Fiscal Year 1977 to receive $\$ 16$ million worth of food coupons. ${ }^{38}$

The most significant measure of the extent of the territory's dependence on the U.S. government, considering all federal assistance, is the fact that more Federal money is spent in the U.S. Virgin Islands per capita than in any other U.S. jurisdiction, while at the same time the per capita tax effort in the Virgin Islands is the lowest under the American flag. ${ }^{39}$

It is this financial dependence on Washington's munificence, aside from substantial dependence on the mainland for support of the private sector in the Islands, ${ }^{40}$ that leads many Virgin Islanders to scoff 
at the idea of independence as a feasible future option for the Islands. On the other hand, there are many examples in the Eastern Caribbean and elsewhere in the world where nationalism has transcended economic dependence on metropolitan powers, and where the popular motivation for independence has prevailed.

Other Options

The other major status option is integration which can assume the forms of statehood or what may be termed simply "fuller integration." Each would entail greater autonomy and control of internal affairs and greater participation in the national political system. Statehood would mean that the Virgin Islands would be admitted to the United States as a co-equal state, and is generally conceded the least likely possibility. Fuller integration would mean a status short of statehood but more equal political treatment, and-depending upon its provisions-might require amendment of the U.S. Constitution, a most difficult process at best.

Remaining options generally are referred to as commonwealth and/or free association, which presumably imply local control over internal affairs, the retention of defense and most foreign affairs by the United States, and Congressional constraint in exercising its authority. How different these options are from each other is a matter of dispute. Indeed, the nearest equivalent to an English term for free associated state is commonwealth. But the term in Spanish-Estado Libre Associado-implies more political autonomy than Puerto Rico possesses. The Commonwealth of the Northern Mariana Islands, a status approved by Congress in 1976, has more governmental power than that granted Puerto Rico.

Congress in 1950 empowered Puerto Ricans to draft their own constitution which they adopted in 1952 and the new commonwealth government came into being. Puerto Rico's new commonwealth status enabled the United States to end its embarrassment of having to submit yearly reports to a United Nations agency that dealt with colonies. Whether Puerto Rico today is actually self-governing under the U. N.'s standards, however, is still a live issue in the United Nations decolonization committee. It must be noted that Puerto Rico achieved its commonwealth status when the United States dominated the United Nations, and it is doubtful that- were the decision to be made today-the United Nations would drop Puerto Rico from its list of non-self-governing territories. Congress still has plenary power over Puerto Rico, and it is still under the territorial clause of the Constitution. Despite its so-called commonwealth or free association status, Puerto Rico is clearly a non-self-governing territory. It is doubtful, therefore, that the United Nations would consider either commonwealth or free association a sufficient status to drop the U.S. Virgin Islands from its list of non-self-governing territories.

\section{Conclusion}

Juxtaposed against their affinity with the rapidly decolonized Eastern Caribbean are the Virgin Islands' economic bonds with the United States. It is unlikely that Virgin Islanders would readily sever or loosen these bonds in exchange for a radically different political status. The important matter, however, is that the people of the Virgin Islands should have the right to choose the political status they prefer, assuming a majority can agree on one of the options. In a poll conducted by Lou Harris and Associates in April 1981, 55 percent of Virgin Islanders were reported to feel that the territory should have closer ties to the United States, 32 percent felt the present relationship should remain, and 13 percent favored complete independence. At present, therefore, a form of closer integration with the U.S. other than statehoood appears a likely choice of Virgin Islanders. Assuming they would choose fuller integration, certain principles would need to be observed for them to enjoy self-determination and a greater measure of self-government.

The so-called territorial clause of the United States Constitution-Article IV, section 3, clause 2states: "The Congress shall have power to dispose of and make needful Rules and Regulations respecting the Territory or other Property belonging to the United States ..." This clause has been used to justify Congressional and executive action predicated on the assumption of absolute federal authority with respect to U.S. territories. Accordingly, the basic principles governing the federal-state relationshipnamely, equality of treatment and limitation of federal power-are not extended to the territories. They should be! 
Assurance of civil liberties of the people of the Virgin Islands is no longer a key issue. All civil liberties in the U.S. Constitution, except indictment by grand jury, likewise protect residents of the Virgin Islands. Today the key issues are participation in the national political system and territorial control over territorial affairs. The territory of the Virgin Islands does not participate as an entity in Congress because it has only a single nonvoting representative in Congress. Citizens of the Virgin Islands are not granted the right to vote for the President and Vice President, and therefore are not represented in the national political system in any meaningful capacity. They should be! The same, of course, could be said of Puerto Rico, Guam, and America Samoa.

The right of self-government is more important than the manner in which that right is exercised. Even should the people of the Virgin Islands govern themselves badly, they should have the right to do so. This means that once Virgin Islanders have created a territorial consititution that has been approved by Congress, Congress should pledge not to override its provisions, and should vest in the Legislature of the Virgin Islands all the powers normally exercised by the various state legislatures. The status of that constitution should be accorded the presumptive equivalence of the Tenth Amendment of the U.S. Constitution. Just as the Tenth Amendment constitutionally restricts national government intrusion upon the reserved powers of the states, so also would the constitution of the Virgin Islands restrict national intrusion upon the powers exercised under its provisions. Once the constitution of the Virgin Islands is approved and adopted, Congress should use the territorial clause of the U.S. Constitution only to advance the development of the Virgin Islands.

Should Virgin Islanders choose fuller integration and should these principles be observed, then selfdetermination for the Virgin Islands will no longer be a myth but a reality.

\section{FOOTNOTES}

${ }^{1}$ Klaus de Albuquerque, Demographic and Socio-Economic Consequences of West Indian Migration to the United States Virgin Islands, unpublished paper presented at the Conference on Intra-Hemispheric Immigration: Multiple Perspectives, October 31November 1, 1980 (xeroxed, Rutgers Institute, New Brunswick, New Jersey), pp. 3, 22-25; Marilyn F. Krigger, Attitudes and References to Immigrants in the St. Thomas Press 1936-1942, unpublished paper presented at the Tenth Conference of Caribbean Historians, March 27-April 1, 1978 (xeroxed, College of the Virgin Islands, St. Thomas, V.I.), pp. 2-3. See, also, William W. Boyer, America's Virgin Islands, A History of Human Rights and Wrongs (Durham, N.C.: Carolina Academic Press, 1983), pp. 166-167, 255-256, 286-292, 327-331; and Mark J. Miller and William W. Boyer, "Foreign Workers in the USVI, History of a Dilemma," Caribbean Review, Vol. XI, No. 1 (Winter, 1982): 48-51.

${ }^{2}$ Chales C. Tansill, The Purchase of the Danish West Indies (Baltimore: The Johns Hopkins Press, 1932), pp. 497-516.

${ }^{3}$ Robert Lansing, Secretary of State at the time, later acknowledged that in the event Denmark refused to sell the Islands, he had threatened U.S. "occupation of the Islands." Robert Lansing, "Drama of the Virgin Islands Purchase," The New York Times Magazine, July 19, 1931, Vol. 80, Sec. 5, p. 4.

4The 1917 Treaty stipulated that persons not choosing to elect Danish citizenship would be deemed to have accepted "citizenship in the United States." Article 6, Convention between the United States and Denmark for the Cession of the Danish West Indies, ratified by the United States, January 25, 1917; 39 Stat. 706. See e.g., Luther H. Evans, The Virgin Islands from Naval Base to New Deal (Ann Arbor, Mich.: J. W. Edwards, 1945), pp. 62-63; and Waldo Evans, The Virgin Islands of the United States, A General Report by the Governor (Washington: Navy Department, 1928), p. 52.

${ }^{5}$ Downes v. Bidwell, 182 U.S. 244 (1901).

6W. W. Willoughby, The Constitutional Law of the United States, 2nd edition (New York: Baker, Voorhis and Company, 1929), vol. 1, p. 476; and Frederic R. Coudert, "Evolution of the Doctrine of Incorporation," Columbia Law Review, vol. 36, p. 832 (1926).

${ }^{7}$ For discussion of the so-called Insular Cases, see William W. Boyer, Civil Liberties in the U.S. Virgin Islands, 1917-1949 (St. Croix, USVI: Antilles Graphic Arts, 1982), pp. 2-17.

8See, e.g., Isaac Dookhan, "The Search for Identity: The Political Aspirations and Frustrations of Virgin Islanders under the United States Naval Administration, 1917-27," xeroxed, College of the Virgin Islands, August 1977, subsequently published in The Journal of Caribbean History, vol. 12, 1979; Isaac Dookhan, "Civil Rights and Political Justice: The Role of the American Civil Liberties Union in the U.S. Virgin Islands, 1920-1936," xeroxed, College of the Virgin Islands, August 1982, also scheduled for publication as a journal article; and Gordon K. Lewis, The Virgin Islands: A Caribbean Lilliput (Evanston, Ill.: Northwestern University Press, 1972), pp. 42-67.

${ }^{9}$ Governor of the Virgin Islands to Secretary of Navy via Director of Naval Intelligence, in the United States National Archives and Record Services in Washington, D.C. (hereafter cited as: NARS), Record Group (hereafter cited as: RG) 55/2, File 62, February $3,1919$.

10Governor Kittelle to President Harding, NARS, RG 55/2, File 62-1, February 27, 1922.

${ }^{11}$ C.C. Timmons, Government Secretary, to Elizabeth Harrington, NARS, RG 55/2, File 62-1, May $27,1921$.

12The New York Times, March 27, 1931, p. 1, col. 3, and p. 23, col. 3.

13The New York Times, March 30, 1931, p. 10, col. 2.

14John Frederick Grede, The New Deal in the Virgin Islands 1931-1941 (unpublished Ph.D. dissertation, University of Chicago, 1963), pp. 132-134.

${ }^{15}$ Report of a mass meeting, Casper Holstein presiding, held under the auspices of the Virgin Islands Congressional Council and Allied Virgin Islands Societies at Frederick Douglas High School, No. 139, 140th Street, New York City, in NARS, RG 126, File 9-11-2, Part 3, November 25, 1934. 
16The Organic Act of the Virgin Islands of the United States, 49 Stat. 1807 (1936).

17The Revised Organic Act of the Virgin Islands of the United States, 68 Stat. 497 (1954).

18James A. Bough, "Is Commonwealth Status the Next Step?" The Virgin Islands Bar Journal, vol. 5, no. 1 (Summer 1974$): 9$.

19Letter to the Editor from Earle B. Ottley, Chairman of the Virgin Islands Organic Act Commission, Charlotte Amalie, St.

Thomas, V. I., January 4, 1958, The New York Times, January 12, 1958, sec. 4, p. 10, col. 7.

20Darwin D. Creque, The U.S. Virgin Islands and the Eastern Caribbean (Philadelphia: Whitmore Publishing Co., 1968), pp. 165-166.

${ }^{21}$ Valdemar A. Hill, Sr., Rise to Recognition, An Account of U.S. Virgin Islanders from Slavery to Self-Government (St. Thomas,

U.S.V.I.: St. Thomas Graphics Inc., 1971), p. 145.

22See: The New York Times, November 6, 1955, p. 11, col. 2; January 19, 1960, p. 22, col. 3; February 23, 1960, p. 63, col. 1; January 17, 1961, p. 22, col. 3; July 25, 1960, p. 14, col. 3; October 15, 1960, p. 21, col. 3; and Annual Report of the Governor of the Virgin Islands, 1958, pp. 16, 18.

${ }^{23}$ Hearings before the Senate Committee on Interior and Insular Affairs, Nomination for Governor of the Virgin Islands, 87th Cong., 1st sess., March 10, 11, and 14, 1961, pp. 675-677.

2173 Stat. 569 (1968).

${ }^{26}$ For commentary concerning these enactments, see Isaac Dookhan, A History of the Virgin Islands of the United States (St.

Thomas, U.S.V.I.: College of the Virgin Islands, Caribbean Universities Press, 1974), pp. 293-296.

26Thus, before a Congressional subcommittee, Assistant Attorney General of the Virgin Islands James A. Bough testified in 1970: "This declaration should remove from the minds of the Congress any concern that the grant of a resident commissioner will in any way be a commitment that the Virgin Islands are on the way to statehood." Hearings before the House Subcommittee on Territorial and Insular Affairs, Nonvoting Delegates-Guam and the Virgin Islands, 91st Cong., 2d sess., May 18 and 19, 1970, pp. 75, 76.

27See: Constitution of the Territory of the United States Virgin Islands (1972); and Proposed Virgin Islands Federal Relations

Act as approved by Second Constitutional Convention of the Virgin Islands (August 10, 1972).

28Public Law 94-584 (1976).

29The New York Times, March 11, 1979, sec. 4, p. E5, col. 1.

30United States General Assembly, Special Committee on the Situation with Regard to the Implementation of the Declaration on the Granting of Independence to Colonial Countries and People, Report of the United Nations Visiting Mission to the United States Virgin Islands, 1977, A/AC.109/L.1198, English Edition (New York: United Nations, September 1, 1977 ), pp. 75-76.

${ }^{31}$ Comments of the Governor of the Virgin Islands on the Reports of the Interagency Territorial Policy Review Task Force (Charlotte Amalie, St. Thomas, U.S. Virgin Islands: Office of the Governor, October 12, 1979), xeroxed, p. 4. Governor Luis responded to a preliminary draft, xeroxed, of Reports of the Interagency Territorial Policy Review Task Force released by the White House, September 17, 1979.

32San Juan Star, May 29, 1980, p. 19.

3s"Federal Territorial Policy," Message to the Congress, February 14, 1980, Administration of Jimmy Carter, 1980, Weekly Compilation of Presidential Documents, Monday, February 18, 1980, vol. 16, no. 7, p. 319.

34Statement by President Jimmy Carter to the Democratic Party Platform Committee, June 12, 1980, pp. 61-62.

${ }^{36}$ See Benita Akin, "Anti-Status Commission Group for 'Self-Determination,"” The Daily News (St. Thomas), August 3, 1981, pp. 3, 17.

36Interview, E. Charles Downs, Office of Territorial Affairs, U.S. Department of the Interior, Washington, D.C., August $14,1979$. 37Richard W. Miller, The Economy of the Virgin Islands (Washington, D.C.: Office of Territorial Affairs, Department of the Interior, June 20, 1979), pp. 44-48.

38See: Editorial, "Staggering Statistics," The St. Croix Avis, May 27, 1975; and Kwame Garcia, "Food Stamps: Who Benefits?" The Daily News (St. Thomas), August 25, 1978, pp. 9, 13.

39U.S. Comptroller for the Virgin Islands, Report to the Secretary of Interior on the Requirements of Public Law 95-348 (Charlotte Amalie, St. Thomas, June 1979), pp. 3-5; and Miller, The Economy of the Virgin Islands, pp. 42-43.

$40^{\circ}$ The 1.2 million visitors to the U.S. Virgin Islands in 1982 spent $\$ 314.8$ million, an average of $\$ 262$ per visitor or $\$ 98$ per visitor day, and . . 45 cents out of every dollar of the government payroll came from tax collections generated by the tourism industry." John Collins, "Figures Show Tourism's Value to Virgin Islands," Caribbean Business (San Juan, P.R.), August 3, 1983, p. 20. Hess Oil Virgin Islands Corporation (a subsidiary of Amerada-Hess), which operates the world's largest oil refinery on St. Croix, a construction firm subcontracted by Hess, and Martin-Marietta Aluminum Inc., which operates a large bauxite processing plant on St. Croix, are the three leading employers among 100 largest private sector employers in the Virgin Islands. John Collins, "Hess Oil Largest Among Private V.I. Employers," ibid., p. 21. 